Published in final edited form as:

Adv Exp Med Biol. 2010 ; 695: 155-168. doi:10.1007/978-1-4419-7037-4_11.

\title{
ADULT STEM CELLS AND THEIR NICHES
}

\author{
Francesca Ferraro and Cristina Lo Celso \\ David Scadden * \\ David Scadden- Harvard Stem Cell Institute, Massachusetts General Hospital, Department of \\ Stem Cell and Regenerative Biology, Harvard University, 185 Cambridge Street, Boston, \\ Massachusettes, USA. dscadden@mgh.harvard.edu
}

\begin{abstract}
Stem cells participate in dynamic physiologic systems that dictate the outcome of developmental events and organismal stress, Since these cells are fundamental to tissue maintenance and repair, the signals they receive play a critical role in the integrity of the organism. Much work has focused on stem cell identification and the molecular pathways involved in their regulation. Yet, we understand little about how these pathways achieve physiologically responsive stem cell functions. This chapter will review the state of our understanding of stem cells in the context of their microenvironment regarding the relation between stem cell niche dysfunction, carcinogenesis and aging.
\end{abstract}

\section{THE NICHE CONCEPT, DEFINITION AND HISTORICAL BACKGROUND}

The stem cell niche is the in vivo microenvironment where stem cells both reside and receive stimuli that determine their fate. Therefore, the niche should not be considered simply a physical location for stem cells, rather as the place where extrinsic signals interact and integrate to influence stem sell behavior. These stimuli include cell-to-cell and cellmatrix interactions and signals (molecules) that activate and/or repress genes and transcription programs. As a direct consequence of this interaction, stem cells are maintained in a dormant state, induced to self-renewal or commit to a more differentiated state.

Schoefield first postulated the hypothesis of a specialized stem cell microenvironment in 1978. ${ }^{1}$ He proposed that niches have a defined anatomical location and also that removal of stem cells from their niche results in differentiation. The first demonstration and characterization of niche components was conducted in the invertebrate model of Drosophila melanogaster and Caenorhabditis elegans gonads. ${ }^{2,3}$ Examination of these systems, characterized in less complex animals, has led to pivotal insights into understanding the more complex mammalian niche architecture. It appears that the fundamental anatomical components and molecular pathways of the niche environment are highly conserved among species, although their respective roles within the niche may show distinct variations. Therefore, it has been proposed that it is possible to identify common niche components that are associated with similar functions (Fig. 1).

The general niche model involves the association between resident stem cells and heterologous cell types - the niche cells. However, the existence of a heterologous cell type 
is not essential and components of the extracellular matrix (or other noncellular components) may determine the niche for stem cells. Notably, a niche environment may retain its key functions and properties, even in the temporary absence of stem cells (such as following stem cell depletion through radiation treatment) allowing recruitment and homing of exogenous stem cells to the pre-existing stem cell niche.

Conserved components of the niche are:

1. Stromal support cells, including cell-cell adhesion molecules and secreted soluble factors, which are found in close proximity to stem cells.

2. Extracellular matrix (ECM) proteins that act as a stem cell "anchor" and constitute a mechanical scaffolding unit to transmit stem cell signaling.

3. Blood vessels that carry nutritional support and systemic signals to the niche from other organs and also participate in the recruitment of circulating stem cells from and to the niche.

4. Neural inputs that favor the mobilization of stem cells out of their niches and integrate signals from different organ systems. Neuronal cues appear to be particularly important in hematopoietic stem cells trafficking. ${ }^{4}$

Given the profound effect of the niche environment on stem cell behavior, newer work is exploring how niche perturbations may cause stem cell dysfunctions, as it is seen in aging or neoplastic transformation. ${ }^{5-9}$

\section{STEM CELL NICHE COMPONENTS}

In the invertebrate model of Drosophila ovary, germinal stem cells (GSCs) located in the germarium are in physical contact with cap cells and terminal filaments cells. During the process of asymmetric division, GSCs that physically contact cap cells through E-cadherin junctions retain their stem cell properties, whereas those cells that lose contact with cap cells differentiate into mature follicle cells. A similar system, driven by polarity cues, applies also for Drosophila testis, where two sets of stem cells, germinal stem cells (GSCs) and somatic stem cells (SSCs) are associated at the apical tip of the testis with hub cells. Daughter cells that detach from the hub initiate a differentiation program to become, respectively, spermatogonia and somatic cyst cells. In C. elegans 225 germ cells are associated to distal tip cells (DTC) and they are maintained stem cells through signals from these cells.

Several niches have been identified also in many mammalian tissues: hematopoietic system, skin, intestine, brain and muscle (Fig. 2).

In trabecular bone marrow, hematopoietic stem and progenitor cells (HSPCs) reside along the endosteal surface close to osteoblasic cells ${ }^{10,11}$ and in proximity to the blood vessels. ${ }^{12,13}$ Since a niche is defined by its functional regulation of stem cells, the mere physical proximity of stem cells to other components is insufficient to determine if those components are niche elements. To date, data indicating a regulatory role for osteoblastic cells has several lines of support but a role for endothelium is less clear. ${ }^{10,11,14-16}$ 
In the skin, epithelial stem cells (ESCs) are found in the bulge area of the hair follicles. ${ }^{17}$ While the exact components of skin niche have not been fully identified yet, although critical regulatory cues derive from the dermal papilla. These stem cells are important in regeneration of hair follicles while scattered stem cells attached to the basal membrane that separates epidermis from dermis (basal keratinocytes) are involved in replacement of interfollicular epidermidis. ${ }^{18}$ Sebaceous glands are maintained by cells at the base of each gland, ${ }^{19}$ but their niche is still largely unknown.

In adult central nervous system, neural stem cells (NSCs) have been identified in the lateral subventricular zone (SVZ) and in the subgranular zone (SGZ) of the dentate gyrus within the hippocampus. ${ }^{20-22}$ Within these areas neural stem cells have been shown to express the astorcyte marker glial fibrillary acidic protein (GFAP). GFAP-positive astrocytes in SVZ and SGZ are able to give rise to neuroblasts and subsequently mature neurons. Located in close proximity to NSCs, endothelial cells are considered niche cells in the central nervous system. ${ }^{22}$

In the gut, intestinal stem cells (ISCs) reside in the bottom part of the intestinal crypt interdigitated between Paneth cells. ${ }^{23}$ The area surrounding the crypts is particularly rich of enteric neurons and blood vessels. Specialized mesenchymal cells also known as myofibroblasts in close proximity to crypt cells and have been suggested to be niche cells for ISCs. ${ }^{24}$

In the muscle, stem cells, known as satellite cells, are located along muscle fiber tracts attached to the plasma membrane that surrounds each muscle fiber bundle. In this case the basal lamina may represent the niche for satellite cells. ${ }^{25,26}$

\section{MOLECULAR PATHWAYS ASSOCIATED WITH NICHE FUNCTION}

Molecules that influence fate determination of stem cells are secreted from niche cells and may exert their function either through paracrin effects or through neural output (neuroendocrine effect).

Molecular pathways recognized to be important modulators of stem cell maintenance and function are redundant in different niches but have different roles according to the specific niche. These pathways include Wnt/beta-catenin, bone morphogenetic protein (BMP), Notch, Angiopoietin-1 (Ang-1) and several growth factors, such as fibroblast growth factor (FGF), insulin growth factor (IGF), vascular endothelial growth factor (VEGF), transforming growth factor-alpha (TGF-alpha) and platelet derived growth factor (PDGF). Among these, BMP and Wnt signaling appear to be highly conserved controlling selfrenewal and lineage commitment in both invertebrates and mammals.

Wnt/beta-catenin signaling may exert differential effects depending on the tissue. For instance, in the hematopoietic system ${ }^{27}$ and intestine ${ }^{28,29} \mathrm{Wnt} /$ beta-catenin is an important mediator of self-renewal and proliferation of stem cells, while in the skin it promotes differentiation of hair follicole precursors. ${ }^{30-32}$ In mammalian brain, over-expression of beta-catenin through Wnt signaling leads to the expansion of neuronal stem cells populations. ${ }^{33}$ 
Bone morphogenic protein (BMP) signaling plays an important role in the control of $D$. melanogaster GCS expansion by repressing expression of bam, ${ }^{34}$ the mediator of cystoblast differentiation. BMP signals are also generated in Drosophila testis' hub cells and are required for the control of GCS self-renewal. In the hematopoietic system, BMP plays an important role in control of HSC number ${ }^{11}$ while in the skin, BMP signals act opposite to Wnt signaling, inhibiting the activation of follicle stem cells and favoring epidermal cell fate. ${ }^{35,36}$ In central nervous system, BMP signals favor the differentiation of NSC towards astrocytes while the BMP inhibitor, Noggin, promotes a neurogenic fate. ${ }^{37}$ Notch signaling pathways are required to maintain stem cells in undifferentiated states in most of these systems, however it triggers differentiation of epidermal progenitor cells.

In addition to the above-mentioned secreted proteins, other molecules such as ions, oxygen and reactive oxygen species (ROS) act on stem cells to affect their behavior. In bone marrow for instance, high calcium concentrations are found in proximity of the endosteal surface, the site of active bone remodeling where both osteoblasts and osteoclasts are found in close proximity. HSCs normally express the calcium sensing receptor $(\mathrm{CaR})$ and its deletion results in HSC abnormal function leading to an impaired marrow engraftment. ${ }^{38}$ Further research indicates that HSC preferential localization follows a hypoxic gradient and also that ROS can lead to a premature HSC senescence. ${ }^{39}$ These components are summarized in Table 1.

\section{EXTRACELLULAR MATRIX AND CELL-CELL INTERACTIONS}

The ECM acts as a scaffolding system, in which stem cells, stromal cells and molecular cues are embedded. Its role is to retain the stem cells in place, to localize signals and to create gradients that guide stem cells in their processes of self-renewal and differentiation. Examples of these key properties are represented by beta- 1 integrins that are expressed in various stem cells types, such as HSCs, ${ }^{40}$ skin $^{41-43}$ and muscle stem cells ${ }^{44}$ and that mediates stem cells adhesion to matrix components, regulating stem cell maintenance. Deletion of beta integrins, however, do not lead to loss of marrow stem cells ${ }^{45}$ suggesting that additional factors are involved in HSC localization. ${ }^{46,47}$ Tenascin-C is another ECM component expressed in the stromal compartment of the brain ${ }^{48}$ and bone marrow. ${ }^{49}$ In the brain, it increases sensitivity of NSCs to fibroblast growth factor 2 (FGF2) and bone morphogenetic protein- 4 (BMP4). ${ }^{48}$ In bone marrow, osteopontin (OPN) is another matrix glycoprotein that interacts with cell adhesion molecules expressed on HSCs, like CD44 and other integrins ${ }^{50,51}$ to facilitate HSC retention in their niche.

It has recently been reported that several mechanical characteristic of ECM, such as the grade of stiffness and elasticity, are involved in stem cell differentiation by means of affecting lineage commitment. ${ }^{52}$ This might be particularly important after tissue injury, where subsequent scar formation might negatively affect the ability of stem cells in repair activity.

As previously indicated in invertebrate models, cell-cell interactions via cadherins proteins and spindle cell orientation represent a well-established system through which cells can undergo symmetric cell division (self-renewal) or asymmetric cell division (commitment/ 
differentiation). ${ }^{53,54}$ It has been suggested that the same system might also be active in the mammalian niche even though substantial evidence for this is still missing. For instance, preliminary studies have shown that $\mathrm{N}$-cadherin facilitates the association between hematopoietic stem cells and osteoblasts, ${ }^{11}$ and that M-cadherin is involved in the association between muscle stem cells and muscle fibers. ${ }^{55}$ However, the loss of $\mathrm{N}$-cadherin and M-cadherin in hematopoietic system and in muscles, respectively, does not translate into overt stem cell dysfunction in either system. ${ }^{56-58}$

\section{STEM CELL NICHE DYNAMISM}

Stem cell niches receive and mediate messages from the periphery about the necessity for tissue repair following stress of injury, so that stem cell function is flexible and adaptable.

In Drosophila, ovary niche cells can induce somatic stem cells to enter the niche and replace lost germline stem cells ${ }^{59}$ and testis niche cells can induce de-differentiation of spermatogonia if the niche needs to be replenished. ${ }^{60}$

In mammalian epidermis, bulge stem cells can migrate upwards and regenerate all epidermal compartments following injury, even though this involvement is only transient and during homeostasis they are only responsible for hair follicle maintenance. ${ }^{61}$ Artificially induced Wnt signaling activation in the basal layer of the epidermis leads to the induction of new dermal papillae and ectopic development of hair follicles, leading to the generation of new stem cell niches as well. ${ }^{62}$

In the Drosophila intestine and mammalian muscle it has been shown that differentiated cells feedback to stem cells inducing them to proliferate in response to injury. ${ }^{63,64}$

The mammalian HSC niche provides perhaps some of the most striking examples of niche dynamism in response to multiple stimuli. For example, it has been shown that the HSC mobilizing agent G-CSF acts in the first place on osteoblasts, inducing them to proliferate. A wave of HSC proliferation follows the osteoblast one and the return of osteoblast numbers to normal accompanies HSC egression from the niche and mobilization to the peripheral blood. ${ }^{65}$ Moreover, the HSC niche is able to survive lethal irradiation, attract freshly transplanted HSC and regenerate itself and the whole hematopoietic tree thanks to complex molecular interactions interactions between osteoblasts, megakaryocytes, endothelial and perivascular cells. ${ }^{15,66}$ The chemokine CXCL12 (also called SDF1) has a crucial role in the HSC niche regeneration process as it is responsible for recruitment and retention of transplanted HSC and regulates neo-vascularization and survival of megakaryocytes and osteoblast progenitors. ${ }^{67-69}$

The development of wound repair assays and of an enormous number of transgenic and knock out model organisms has allowed revealing the plasticity of numerous stem cell niches and studying the molecular mechanisms of tissue regeneration. More recently, the advancement of in vivo imaging technologies lead to direct visualization of transplanted hematopoietic stem cells reaching the bone marrow and initiating the engraftment process. ${ }^{70-73}$ The combination of in vivo cell tracking and precise stem cell and lineage marking is currently the most promising strategy to evaluate the dynamic response on adult 
stem cell niches to tissue injury. ${ }^{74}$ Further, setting of physiologic stress can see the development of new niches. In hematopoiesis, the infiltration of the bone marrow by abnormal cells (e.g., hemoglobinopathies) can result in hematopoiesis occurring in ectopic sites like limph node, spleen and liver.

\section{STEM CELL NICHE AGING}

The aging process affects not only the stem cells but also their microenvironment. In several aged tissues stem cells are more proliferative but less efficient in terms of self renewal and progeny production (see for example Drosophila intestinal stem cells ${ }^{75}$ and mammalian hematopoietic stem cells).$^{76}$ Works on Drosophila and mouse gonads demonstrated that stem cells do not age by themselves, but rather aged niches have reduced supportive properties. ${ }^{77-80}$ In fact, when mouse germline stem cells are serially transplanted into the testis of young mice they are able to maintain their function for years. ${ }^{80}$ Young hematopoietic stem cells transplanted into old recipient mice present an aged phenotype at least transiently. ${ }^{81,82}$ Moreover, young HSC transiently exposed in vitro to osteoblasts from old mice perform more similarly to older HSC in transplantation assays. ${ }^{9}$

The deregulation of local signaling pathways and accumulation of stress-induced damage, including reactive oxygen species (ROS), have been indicated as major causes of stem cell and niche loss of function during aging. Old niches appear to constitutively maintain damage response pathways and mechanisms, which younger niches activate only temporarily in response to injury. In this sense, niche aging might be perceived as a progressive switch from the ability to flexibly respond to damage to a constant, yet inefficient, repair mode, which eventually exhaust the stem cell regenerative potential. ${ }^{75,83-85}$ The same molecular pathways regulating young stem cell-niche interactions are still present in older niches, however signaling the latter is deregulated. Examples the Notch pathway in the Drosophila intestine ${ }^{83}$ and the Wnt pathway in mammalian muscle. ${ }^{6}$

Not only local, but also systemic factors play a role in stem cell and niche aging. While harder to identify, these factors have allowed the first successful experiments leading to stem cell and niche rejuvenation. Older mice exposed to younger systemic factors through parabiosis experiments (in which two animals are surgically joined and develop communal circulation) present rejuvenated muscle and hematopoietic stem cells and niches. 6,9

\section{MALIGNANT STEM CELL NICHES}

In the same way the microenvironment has a critical role in regulating stem cell function, the niche and niche alterations can play a role in the development of cancer. The idea that the microenvironment might be one of the factors involved in cancer development was proposed over one century ago. ${ }^{86}$ The role of local vasculature in the support of tumor growth has long been recognized 87,88 and development of anti-angiogenic molecules has been a very fertile field of basic and translational research aiming at the generation of efficient anticancer therapies. ${ }^{89}$ Transcriptional profiling of basal cell carcinoma cells and stroma indicated that tumor fibroblasts express high levels of Gremlinl, antagonizing BMP 2 and 4 , suppressing epidermal cells differentiation and promoting local proliferation..$^{90}$ Also 
in breast cancer, cancer associated fibroblasts have been demonstrated to be able to promote tumor progression. ${ }^{91}$ Immune cells play a dual role in the regulation of cancer development. On one side they provide immunosurveillance and can actively remove transformed cells from tissues; on the other side chronic inflammation contributes to skewing local molecular signals towards a chronic stress-response, conducive to cell now supportive of tumor growth. ${ }^{92,93}$

Moreover, as stem cells have been described to be the cell of origin of certain malignancies, it is likely that defect in their microenvironment could have contributed to their malignant phenotype. There are some examples of niche/microenvironment knock out mice have been described to develop myeloproliferative or myelodisplastic syndromes which are not transplantable, but rather present again when the mice receive wild type bone marrow transplantation. ${ }^{94-96}$ For example deletion of Dicer1 in a select subset of mesenchymal cells, osetoprogenitors, results in the development of myelodisplasia and remarkably, acute leukemia. The leukemia had secondary genetic changes but had normal Dicer1. Further transplant of the leukemia was only successful if the recipient had deletion of Dicer1 in the marrow osteoprogenitors. Therefore, this niche can be the source of an initiating oncogenic event in cancer and be required for its maintenance. ${ }^{97}$

Recently, the application of the stem cell model to cancer naturally raises the question whether cancer stem cells reside in and are regulated by specific microenvironments and whether they do so in competition with normal stem cells. The answer is complex and variable depending on the cancer analyzed. Human B cell leukemia cells transplanted into mice localize in the bone marrow following the expression pattern of SDF1 and therefore appear similar to normal HSC. ${ }^{13}$ However, it has been shown in a mouse model of chronic myeloid leukemia that malignant, but not normal HSC depend on CD44 function in order to localize to the bone marrow and give rise to leukemia, ${ }^{98}$ indicating the presence of leukemia-specific mechanisms of interaction with the microenvironment. Moreover, it is likely that more aggressive and advanced stages of disease become independent from niche support. Even though leukemia could develop independent of the influence of the microenvironment, in certain cases cytokines and other secreted factors produced by stroma cells have been shown to confer resistance to chemotherapeutic interventions. ${ }^{99,100}$ The differential support of normal and malignant cells by niche alterations represents new promising area for research. If distinct sensitivity to niche signals exists then distinct sensitivity to niche signals can be exploited in therapy.

Tumor progression can alter existing niches at the expenses of normal stem cells. For example, at advanced stages of disease leukemia cells in the bone marrow prevent normal transplanted HSC from correctly localizing in their niches and actively secrete SCF to form a new, inhibitory niche. ${ }^{101}$ Myeloma cells disrupt the endosteal HSC niche by secreting the Wnt inhibitor Dkk1. ${ }^{102}$

Invasive primary tumors secrete soluble factors that can act at long distances to induce premetastatic niches, which in turns will recruit tumor cells and support metastatic growth. ${ }^{103}$ For example, melanoma cells produce factors that activate hepatic stellate cells to become similar to myofibroblasts and supportive of metastatic melanoma cells. ${ }^{104,105}$ 
Finally, normal niches can attract malignant cells with similar characteristics to the stem cells normally residing in the niche. This is the case of the bone marrow, where osteotropic cancers such as breast, ovarian, prostate and neuroblastoma metastatize to based on the SDF1-CXCR4 signaling axis. ${ }^{103}$

\section{CONCLUSION}

The stem cell niche concept has gained experimental support and conceptual complexity since proposed by Schofield. The crosstalk between different cell types intrinsic to the stem cell niche offers the opportunity to target these cell communication networks and tailor the dynamics of normal stem cells to boost their ability to respond to injury as well as to manage the competitive advantage of malignant cells. The niche is a point of intervention still underexplored, that offers a uniquely drug-gable opportunity to affect regenerative medicine and anticancer treatments.

\section{REFERENCES}

1. Schofield R. The relationship between the spleen colony-forming cell and the haemopoietic stem cell. Blood Cells. 1978; 4(1-2):7-25. [PubMed: 747780]

2. Xie T, Spradling AC. decapentaplegic is essential for the maintenance and division of germline stem cells in the Drosophila ovary. Cell. 1998; 94(2):251-260. [PubMed: 9695953]

3. Kimble JE, White JG. On the control of germ cell development in Caenorhabditis elegans. Dev Biol. 1981; 81(2):208-219. [PubMed: 7202837]

4. Katayama Y, Battista M, Kao WM, et al. Signals from the sympathetic nervous system regulate hematopoietic stem cell egress from bone marrow. Cell. 2006; 124(2):407-421. [PubMed: 16439213]

5. Conboy IM, Conboy MJ, Wagers AJ, et al. Rejuvenation of aged progenitor cells by exposure to a young systemic environment. Nature. 2005; 433(7027):760-764. [PubMed: 15716955]

6. Brack AS, Conboy MJ, Roy S, et al. Increased Wnt signaling during aging alters muscle stem cell fate and increases fibrosis. Science. 2007; 317(5839):807-810. [PubMed: 17690295]

7. Zhu Y, Ghosh P, Charnay P, et al. Neurofibromas in NF1: Schwann cell origin and role of tumor environment. Science. 2002; 296(5569):920-922. [PubMed: 11988578]

8. Trimboli AJ, Cantemir-Stone CZ, Li F, et al. Pten in stromal fibroblasts suppresses mammary epithelial tumours. Nature. 2009; 461(7267):1084-1091. [PubMed: 19847259]

9. Mayack SR, Shadrach JL, Kim FS, et al. Systemic signals regulate ageing and rejuvenation of blood stem cell niches. Nature. 2010; 463(7280):495-500. [PubMed: 20110993]

10. Calvi LM, Adams GB, Weibrecht KW, et al. Osteoblastic cells regulate the haematopoietic stem cell niche. Nature. 2003; 425(6960):841-846. [PubMed: 14574413]

11. Zhang J, Niu C, Ye L, et al. Identification of the haematopoietic stem cell niche and control of the niche size. Nature. 2003; 425(6960):836-841. [PubMed: 14574412]

12. Kiel MJ, Yilmaz OH, Iwashita T, et al. SLAM family receptors distinguish hematopoietic stem and progenitor cells and reveal endothelial niches for stem cells. Cell. 2005; 121(7):1109-1121. [PubMed: 15989959]

13. Sipkins DA, Wei $\mathrm{X}, \mathrm{Wu}$ JW, et al. In vivo imaging of specialized bone marrow endothelial microdomains for tumour engraftment. Nature. 2005; 435(7044):969-973. [PubMed: 15959517]

14. Visnjic D, Kalajzic Z, Rowe DW, et al. Hematopoiesis is severely altered in mice with an induced osteoblast deficiency. Blood. 2004; 103(9):3258-3264. [PubMed: 14726388]

15. Hooper AT, Butler JM, Nolan DJ, et al. Engraftment and reconstitution of hematopoiesis is dependent on VEGFR2-mediated regeneration of sinusoidal endothelial cells. Cell Stem Cell. 2009; 4(3):263-274. [PubMed: 19265665] 
16. Jung Y, Wang J, Song J, et al. Annexin II expressed by osteoblasts and endothelial cells regulates stem cell adhesion, homing and engraftment following transplantation. Blood. 2007; 110(1):8290. [PubMed: 17360942]

17. Cotsarelis G, Sun TT, Lavker RM. Label-retaining cells reside in the bulge area of pilosebaceous unit: implications for follicular stem cells, hair cycle and skin carcinogenesis. Cell. 1990; 61(7): 1329-1337. [PubMed: 2364430]

18. Levy V, Lindon C, Harfe BD, et al. Distinct stem cell populations regenerate the follicle and interfollicular epidermis. Dev Cell. 2005; 9(6):855-861. [PubMed: 16326396]

19. Blanpain C, Fuchs E. Epidermal homeostasis: a balancing act of stem cells in the skin. Nat Rev Mol Cell Biol. 2009; 10(3):207-217. [PubMed: 19209183]

20. Doetsch F, Caille I, Lim DA, et al. Subventricular zone astrocytes are neural stem cells in the adult mammalian brain. Cell. 1999; 97(6):703-716. [PubMed: 10380923]

21. Palmer TD, Takahashi J, Gage FH. The adult rat hippocampus contains primordial neural stem cells. Mol Cell Neurosci. 1997; 8(6):389-404. [PubMed: 9143557]

22. Shen Q, Goderie SK, Jin L, et al. Endothelial cells stimulate self-renewal and expand neurogenesis of neural stem cells. Science. 2004; 304(5675):1338-1340. [PubMed: 15060285]

23. Barker N, van Es JH, Kuipers J, et al. Identification of stem cells in small intestine and colon by marker gene Lgr5. Nature. 2007; 449(7165):1003-1007. [PubMed: 17934449]

24. Mills JC, Gordon JI. The intestinal stem cell niche: there grows the neighborhood. Proc Natl Acad Sci USA. 2001; 98(22):12334-12336. [PubMed: 11675485]

25. Mauro A. Satellite cell of skeletal muscle fibers. J Biophys Biochem Cytol. 1961; 9:493-495. [PubMed: 13768451]

26. Kuang S, Kuroda K, Le Grand F, et al. Asymmetric self-renewal and commitment of satellite stem cells in muscle. Cell. 2007; 129(5):999-1010. [PubMed: 17540178]

27. Reya T, Duncan AW, Ailles L, et al. A role for Wnt signalling in self-renewal of haematopoietic stem cells. Nature. 2003; 423(6938):409-414. [PubMed: 12717450]

28. Brittan M, Wright NA. Gastrointestinal stem cells. J Pathol. 2002; 197(4):492-509. [PubMed: 12115865]

29. Brittingham J, Phiel C, Trzyna WC, et al. Identification of distinct molecular phenotypes in cultured gastrointestinal smooth muscle cells. Gastroenterology. 1998; 115(3):605-617. [PubMed: 9721158]

30. Huelsken J, Vogel R, Erdmann B, et al. beta-Catenin controls hair follicle morphogenesis and stem cell differentiation in the skin. Cell. 2001; 105(4):533-545. [PubMed: 11371349]

31. Merrill BJ, Gat U, DasGupta R, et al. Tcf3 and Lef1 regulate lineage differentiation of multipotent stem cells in skin. Genes Dev. 2001; 15(13):1688-1705. [PubMed: 11445543]

32. Niemann C, Owens DM, Hulsken J, et al. Expression of DeltaNLef1 in mouse epidermis results in differentiation of hair follicles into squamous epidermal cysts and formation of skin tumours. Development. 2002; 129(1):95-109. [PubMed: 11782404]

33. Chenn A, Walsh CA. Regulation of cerebral cortical size by control of cell cycle exit in neural precursors. Science. 2002; 297(5580):365-369. [PubMed: 12130776]

34. Chen D, McKearin D. Dpp signaling silences bam transcription directly to establish asymmetric divisions of germline stem cells. Curr Biol. 2003; 13(20):1786-1791. [PubMed: 14561403]

35. Botchkarev VA, Botchkareva NV, Nakamura M, et al. Noggin is required for induction of the hair follicle growth phase in postnatal skin. FASEB J. 2001; 15(12):2205-2214. [PubMed: 11641247]

36. Kulessa H, Turk G, Hogan BL. Inhibition of Bmp signaling affects growth and differentiation in the anagen hair follicle. EMBO J. 2000; 19(24):6664-6674. [PubMed: 11118201]

37. Temple S. The development of neural stem cells. Nature. 2001; 414(6859):112-117. [PubMed: 11689956]

38. Adams GB, Chabner KT, Alley IR, et al. Stem cell engraftment at the endosteal niche is specified by the calcium-sensing receptor. Nature. 2006; 439(7076):599-603. [PubMed: 16382241]

39. Ito K, Hirao A, Arai F, et al. Regulation of oxidative stress by ATM is required for self-renewal of haematopoietic stem cells. Nature. 2004; 431(7011):997-1002. [PubMed: 15496926] 
40. Wagers AJ, Allsopp RC, Weissman IL. Changes in integrin expression are associated with altered homing properties of Lin(-/lo)Thy1.1(lo)Sca-1(+)c-kit(+) hematopoietic stem cells following mobilization by cyclophosphamide/granulocyte colony-stimulating factor. Exp Hematol. 2002; 30(2):176-185. [PubMed: 11823053]

41. Brakebusch C, Grose R, Quondamatteo F, et al. Skin and hair follicle integrity is crucially dependent on beta 1 integrin expression on keratinocytes. EMBO J. 2000; 19(15):3990-4003. [PubMed: 10921880]

42. Jones PH, Watt FM. Separation of human epidermal stem cells from transit amplifying cells on the basis of differences in integrin function and expression. Cell. 1993; 73(4):713-724. [PubMed: 8500165]

43. Jensen UB, Lowell S, Watt FM. The spatial relationship between stem cells and their progeny in the basal layer of human epidermis: a new view based on whole-mount labelling and lineage analysis. Development. 1999; 126(11):2409-2418. [PubMed: 10226000]

44. Sherwood RI, Christensen JL, Conboy IM, et al. Isolation of adult mouse myogenic progenitors: functional heterogeneity of cells within and engrafting skeletal muscle. Cell. 2004; 119(4):543554. [PubMed: 15537543]

45. Bungartz G, Stiller S, Bauer M, et al. Adult murine hematopoiesis can proceed without beta1 and beta7 integrins. Blood. 2006; 108(6):1857-1864. [PubMed: 16735603]

46. Fleming WH, Alpern EJ, Uchida N, et al. Steel factor influences the distribution and activity of murine hematopoietic stem cells in vivo. Proc Natl Acad Sci USA. 1993; 90(8):3760-3764. [PubMed: 7682717]

47. Sugiyama T, Kohara H, Noda M, et al. Maintenance of the hematopoietic stem cell pool by CXCL12-CXCR4 chemokine signaling in bone marrow stromal cell niches. Immunity. 2006; 25(6):977-988. [PubMed: 17174120]

48. Garcion E, Halilagic A, Faissner A, et al. Generation of an environmental niche for neural stem cell development by the extracellular matrix molecule tenascin C. Development. 2004; 131(14): 3423-3432. [PubMed: 15226258]

49. Ohta M, Sakai T, Saga Y, et al. Suppression of hematopoietic activity in tenascin-C-deficient mice. Blood. 1998; 91(11):4074-4083. [PubMed: 9596652]

50. Stier S, Ko Y, Forkert R, et al. Osteopontin is a hematopoietic stem cell niche component that negatively regulates stem cell pool size. J Exp Med. 2005; 201(11):1781-1791. [PubMed: 15928197]

51. Nilsson SK, Johnston HM, Whitty GA, et al. Osteopontin, a key component of the hematopoietic stem cell niche and regulator of primitive hematopoietic progenitor cells. Blood. 2005; 106(4): 1232-1239. [PubMed: 15845900]

52. Engler AJ, Sen S, Sweeney HL, et al. Matrix elasticity directs stem cell lineage specification. Cell. 2006; 126(4):677-689. [PubMed: 16923388]

53. Deng W, Lin H. Spectrosomes and fusomes anchor mitotic spindles during asymmetric germ cell divisions and facilitate the formation of a polarized microtubule array for oocyte specification in Drosophila. Dev Biol. 1997; 189(1):79-94. [PubMed: 9281339]

54. Yamashita YM, Jones DL, Fuller MT. Orientation of asymmetric stem cell division by the APC tumor suppressor and centrosome. Science. 2003; 301(5639):1547-1550. [PubMed: 12970569]

55. Irintchev A, Zeschnigk M, Starzinski-Powitz A, et al. Expression pattern of M-cadherin in normal, denervated and regenerating mouse muscles. Dev Dyn. 1994; 199(4):326-337. [PubMed: 8075434]

56. Hollnagel A, Grund C, Franke WW, et al. The cell adhesion molecule M-cadherin is not essential for muscle development and regeneration. Mol Cell Biol. 2002; 22(13):4760-4770. [PubMed: 12052883]

57. Hooper AT, Butler J, Petit I, et al. Does N-cadherin regulate interaction of hematopoietic stem cells with their niches? Cell Stem Cell. 2007; 1(2):127-129. [PubMed: 18371341]

58. Kiel MJ, Radice GL, Morrison SJ. Lack of evidence that hematopoietic stem cells depend on Ncadherin-mediated adhesion to osteoblasts for their maintenance. Cell Stem Cell. 2007; 1(2):204217. [PubMed: 18371351] 
59. Kai T, Spradling A. An empty Drosophila stem cell niche reactivates the proliferation of ectopic cells. Proc Natl Acad Sci USA. 2003; 100(8):4633-4638. [PubMed: 12676994]

60. Brawley C, Matunis E. Regeneration of male germline stem cells by spermatogonial dedifferentiation in vivo. Science. 2004; 304(5675):1331-1334. [PubMed: 15143218]

61. Ito M, Liu Y, Yang Z, et al. Stem cells in the hair follicle bulge contribute to wound repair but not to homeostasis of the epidermis. Nat Med. 2005; 11(12):1351-1354. [PubMed: 16288281]

62. Silva-Vargas V, Lo Celso C, Giangreco A, et al. Beta-catenin and Hedgehog signal strength can specify number and location of hair follicles in adult epidermis without recruitment of bulge stem cells. Dev Cell. 2005; 9(1):121-131. [PubMed: 15992546]

63. Jiang H, Patel PH, Kohlmaier A, et al. Cytokine/Jak/Stat signaling mediates regeneration and homeostasis in the Drosophila midgut. Cell. 2009; 137(7):1343-1355. [PubMed: 19563763]

64. Bischoff R. Interaction between satellite cells and skeletal muscle fibers. Development. 1990; 109(4):943-952. [PubMed: 2226207]

65. Mayack SR, Wagers AJ. Osteolineage niche cells initiate hematopoietic stem cell mobilization. Blood. 2008; 112(3):519-531. [PubMed: 18456874]

66. Dominici M, Rasini V, Bussolari R, et al. Restoration and reversible expansion of the osteoblastic hematopoietic stem cell niche after marrow radioablation. Blood. 2009; 114(11):2333-2343. [PubMed: 19433859]

67. Peled A, Petit I, Kollet O, et al. Dependence of human stem cell engraftment and repopulation of NOD/ SCID mice on CXCR4. Science. 1999; 283(5403):845-848. [PubMed: 9933168]

68. Kortesidis A, Zannettino A, Isenmann S, et al. Stromal-derived factor-1 promotes the growth, survival and development of human bone marrow stromal stem cells. Blood. 2005; 105(10):37933801. [PubMed: 15677562]

69. Jin DK, Shido K, Kopp HG, et al. Cytokine-mediated deployment of SDF-1 induces revascularization through recruitment of CXCR4+ hemangiocytes. Nat Med. 2006; 12(5):557567. [PubMed: 16648859]

70. Kohler A, Schmithorst V, Filippi MD, et al. Altered cellular dynamics and endosteal location of aged early hematopoietic progenitor cells revealed by time-lapse intravital imaging in long bones. Blood. 2009; 114(2):290-298. [PubMed: 19357397]

71. Lewandowski D, Barroca V, Duconge F, et al. In vivo cellular imaging pinpoints the role of reactive oxygen species in the early steps of adult hematopoietic reconstitution. Blood. 2009

72. Lo Celso C, Fleming HE, Wu JW, et al. Live-animal tracking of individual haematopoietic stem/ progenitor cells in their niche. Nature. 2009; 457(7225):92-96. [PubMed: 19052546]

73. Xie Y, Yin T, Wiegraebe W, et al. Detection of functional haematopoietic stem cell niche using real-time imaging. Nature. 2009; 457(7225):97-101. [PubMed: 19052548]

74. Voog J, Jones DL. Stem Cells and the Niche: a dynamic duo. Cell Stem Cell. 2010; 6 in press.

75. Biteau B, Hochmuth CE, Jasper H. JNK activity in somatic stem cells causes loss of tissue homeostasis in the aging Drosophila gut. Cell Stem Cell. 2008; 3(4):442-455. [PubMed: 18940735]

76. Janzen V, Forkert R, Fleming HE, et al. Stem-cell ageing modified by the cyclin-dependent kinase inhibitor p16INK4a. Nature. 2006; 443(7110):421-426. [PubMed: 16957735]

77. Boyle M, Wong C, Rocha M, et al. Decline in self-renewal factors contributes to aging of the stem cell niche in the Drosophila testis. Cell Stem Cell. 2007; 1(4):470-478. [PubMed: 18371382]

78. Hsu HJ, Drummond-Barbosa D. Insulin levels control female germline stem cell maintenance via the niche in Drosophila. Proc Natl Acad Sci USA. 2009; 106(4):1117-1121. [PubMed: 19136634]

79. Pan L, Chen S, Weng C, et al. Stem cell aging is controlled both intrinsically and extrinsically in the Drosophila ovary. Cell Stem Cell. 2007; 1(4):458-469. [PubMed: 18371381]

80. Ryu BY, Orwig KE, Oatley JM, et al. Effects of aging and niche microenvironment on spermatogonial stem cell self-renewal. Stem Cells. 2006; 24(6):1505-1511. [PubMed: 16456131]

81. Liang Y, Van Zant G, Szilvassy SJ. Effects of aging on the homing and engraftment of murine hematopoietic stem and progenitor cells. Blood. 2005; 106(4):1479-1487. [PubMed: 15827136]

82. Rossi DJ, Bryder D, Zahn JM, et al. Cell intrinsic alterations underlie hematopoietic stem cell aging. Proc Natl Acad Sci USA. 2005; 102(26):9194-9199. [PubMed: 15967997] 
83. Ohlstein B, Spradling A. Multipotent Drosophila intestinal stem cells specify daughter cell fates by differential notch signaling. Science. 2007; 315(5814):988-992. [PubMed: 17303754]

84. Brack AS, Rando TA. Intrinsic changes and extrinsic influences of myogenic stem cell function during aging. Stem Cell Rev Fall. 2007; 3(3):226-237.

85. Wagner W, Horn P, Bork S, et al. Aging of hematopoietic stem cells is regulated by the stem cell niche. Exp Gerontol. 2008; 43(11):974-980. [PubMed: 18504082]

86. Paget S. The distribution of secondary growths in cancer of the breast. Lancet. 1889; 1:571-573.

87. Folkman J. Tumor angiogenesis: a possible control point in tumor growth. Ann Intern Med. 1975; 82(1):96-100. [PubMed: 799908]

88. Bergers G, Javaherian K, Lo KM, et al. Effects of angiogenesis inhibitors on multistage carcinogenesis in mice. Science. 1999; 284(5415):808-812. [PubMed: 10221914]

89. Abdelrahim M, Konduri S, Basha R, et al. Angiogenesis: an update and potential drug approaches (review). Int J Oncol. 2010; 36(1):5-18. [PubMed: 19956828]

90. Sneddon JB, Zhen HH, Montgomery K, et al. Bone morphogenetic protein antagonist gremlin 1 is widely expressed by cancer-associated stromal cells and can promote tumor cell proliferation. Proc Natl Acad Sci USA. 2006; 103(40):14842-14847. [PubMed: 17003113]

91. Hu M, Yao J, Carroll DK, et al. Regulation of in situ to invasive breast carcinoma transition. Cancer Cell. 2008; 13(5):394-406. [PubMed: 18455123]

92. Mantovani A, Romero P, Palucka AK, et al. Tumour immunity: effector response to tumour and role of the microenvironment. Lancet. 2008; 371(9614):771-783. [PubMed: 18275997]

93. Raulet DH, Guerra N. Oncogenic stress sensed by the immune system: role of natural killer cell receptors. Nat Rev Immunol. 2009; 9(8):568-580. [PubMed: 19629084]

94. Walkley CR, Olsen GH, Dworkin S, et al. A microenvironment-induced myeloproliferative syndrome caused by retinoic acid receptor gamma deficiency. Cell. 2007; 129(6):1097-1110. [PubMed: 17574023]

95. Walkley CR, Shea JM, Sims NA, et al. Rb regulates interactions between hematopoietic stem cells and their bone marrow microenvironment. Cell. 2007; 129(6):1081-1095. [PubMed: 17574022]

96. Lane SW, Sykes SM, Shahrour F, et al. The APCmin mouse has altered hematopoietic stem cell function and provides a model for cell extrinsic MPD/MDS. Blood. 2010 in press.

97. Raaijmakers MHGP, Mukherjee S, Guo S, et al. Bone progenitor dysfunction induces myelodysplasia and secondary leukemia. Nature. 2010

98. Krause DS, Lazarides K, von Andrian UH, et al. Requirement for CD44 in homing and engraftment of BCR-ABL-expressing leukemic stem cells. Nat Med. 2006; 12(10):1175-1180. [PubMed: 16998483]

99. Iwamoto S, Mihara K, Downing JR, et al. Mesenchymal cells regulate the response of acute lymphoblastic leukemia cells to asparaginase. J Clin Invest. 2007; 117(4):1049-1057. [PubMed: 17380207]

100. Williams RT, den Besten W, Sherr CJ. Cytokine-dependent imatinib resistance in mouse BCRABL+, Arf-null lymphoblastic leukemia. Genes Dev. 2007; 21(18):2283-2287. [PubMed: 17761812]

101. Colmone A, Amorim M, Pontier AL, et al. Leukemic cells create bone marrow niches that disrupt the behavior of normal hematopoietic progenitor cells. Science. 2008; 322(5909):1861-1865. [PubMed: 19095944]

102. Qiang YW, Chen Y, Stephens O, et al. Myeloma-derived Dickkopf-1 disrupts Wnt-regulated osteoprotegerin and RANKL production by osteoblasts: a potential mechanism underlying osteolytic bone lesions in multiple myeloma. Blood. 2008; 112(1):196-207. [PubMed: 18305214]

103. Wels J, Kaplan RN, Rafii S, et al. Migratory neighbors and distant invaders: tumor-associated niche cells. Genes Dev. 2008; 22(5):559-574. [PubMed: 18316475]

104. Olaso E, Salado C, Egilegor E, et al. Proangiogenic role of tumor-activated hepatic stellate cells in experimental melanoma metastasis. Hepatology. 2003; 37(3):674-685. [PubMed: 12601365] 
105. Olaso E, Santisteban A, Bidaurrazaga J, et al. Tumor-dependent activation of rodent hepatic stellate cells during experimental melanoma metastasis. Hepatology. 1997; 26(3):634-642. [PubMed: 9303493] 


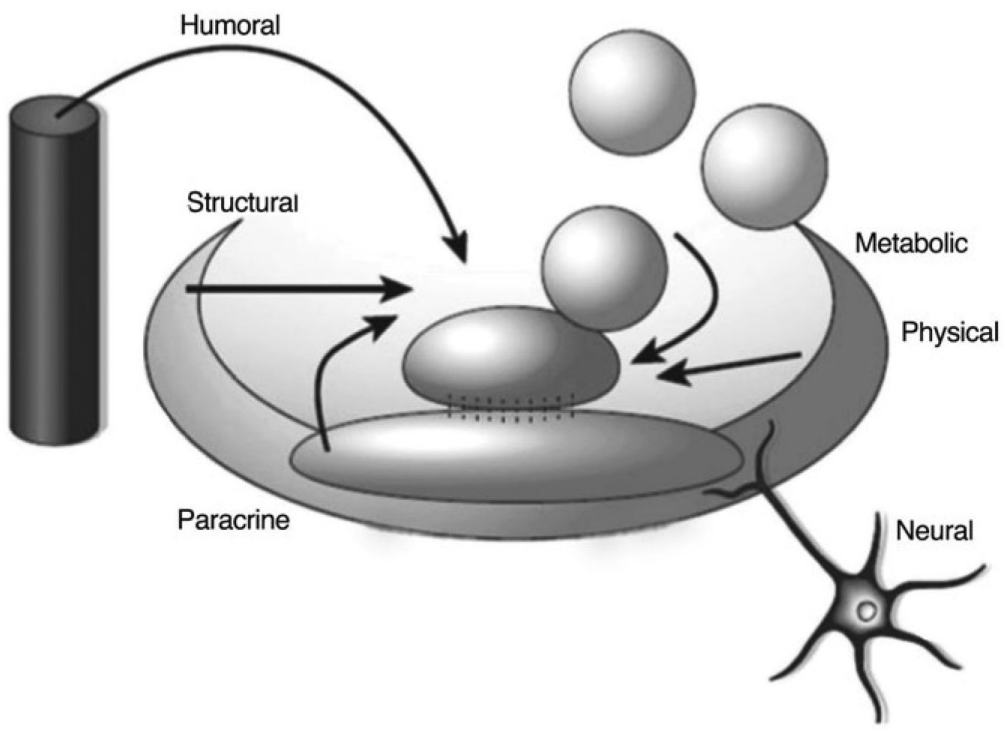

Figure 1.

Representation of a stem cell niche: the stem cell niche is the place where humoral, neuronal, local (paracrine), positional (physical) and metabolic cues interact with each other to regulate stem cell fate. (Adapted from Scadden DT. Nature 441:1075-1079). 

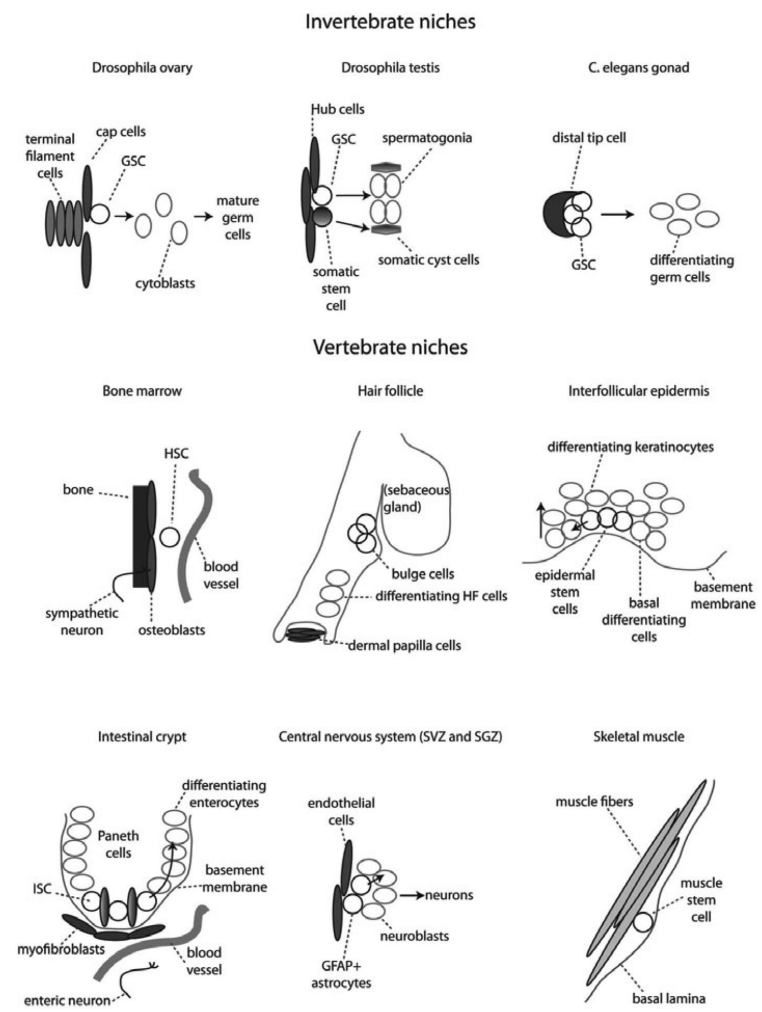

Figure 2.

Stem cell niches. In this figure are shown vertebrate and invertebrate stem cell niches along with their identified components. GSC: germinal stem cell; HSC: hematopoietic stem cell; ISC: intestinal stem cell; SVZ: sub-ventricular zone; SGZ: sub-granular zone; GFAP: glial fibrillary acidic protein. 
Table 1

Summary of cellular and molecular components of known stem cell niches

\begin{tabular}{|c|c|c|c|c|}
\hline Tissue & Stem Cell & Support Cell & Signalling Pathways & Adhesion \\
\hline C. elegans gonad & GSC & Distal tip cell & Notch & NI \\
\hline D. melanogaster testis & GSC & Hub cells & JAK-STAT & DE-cadherin, $\beta$-catenin \\
\hline D. melanogaster ovary & GSC & Cap cells, ESCs & DPP-BMP & DE-cadherin, $\beta$-catenin \\
\hline D. melanogaster testis & $\mathrm{CPC}$ & Hub cells & JAK-STAT & DE-cadherin, $\beta$-catenin \\
\hline D. melanogaster ovary & ESC & NI & JAK-STAT & NI \\
\hline D. melanogaster ovary & FSC & NI & Hedgehog & DE-cadherin, $\beta$-catenin \\
\hline Mouse skeletal muscle & Satellite cells & NI & Notch & $\beta-1$ integrin \\
\hline Mouse bone marrow & HSC & $\begin{array}{l}\text { Osteoblastic cells, } \\
\text { endothelial cells }\end{array}$ & $\begin{array}{l}\text { Wnt, Notch, ANG1, } \\
\text { OPN }\end{array}$ & $\beta-1$ integrin \\
\hline Mouse small intestine & $\mathrm{CBC}$ & $\begin{array}{l}\text { Crypt fibroblasts, Paneth } \\
\text { cells }\end{array}$ & Wnt, BMP & $\beta$-catenin \\
\hline Mouse skin & Inteollicular kerinocyte & NI & Wnt, Shh, Notch & $\begin{array}{l}\text { E-cadherin, } \beta \text {-catenin, } \\
\beta-1 \text { integrin }\end{array}$ \\
\hline Mouse skin & $\begin{array}{l}\text { Follicular bulge stem } \\
\text { cells }\end{array}$ & Dermal fibroblasts & Wnt, BMP & $\beta$-catenin, $\beta$-1 integrin \\
\hline $\begin{array}{l}\text { Mouse brain (latral } \\
\text { ventricle) }\end{array}$ & SVZ stem cells & Vascular cells, astrocytes & Shh, BMP & $\mathrm{N}$-cadherin, $\beta$-catenin \\
\hline Rat brain (hippocampus) & SVZ stem cells & Vascular cells, astrocytes & Shh, Wnt & $\mathrm{N}$-cadherin, $\beta$-catenin \\
\hline
\end{tabular}

ANG1: angiopoietin-1; BNP: bone morphogenetic protein; CBC: crypt base columnar cell; C. elegans: Caenorabditis elegans; CPC: cyst progenitor cell (somatic stem cell); DPP: Decapentaplegic; D. melanogaster: Drosophila melanogaster; ECM: extracellular matrix; ESC: escort stem cell; FSC: follicle stem cell; GSC: germinal stem cell; HSC: hematopoietic stem cell; ISC: intestinal stem cell; JAK: Janus kinase; NI: none identified; OPN: osteopontin; SGZ: subgranular zone; Shh: sonic hedgehog; STAT: Signal transducer and activator of transcriptions; SVZ: subventricular zone. 